\title{
ASM leadership and management
}

\author{
Robert M. Timm* and Suzanne B. McLaren \\ Department of Ecology \& Evolutionary Biology and Biodiversity Institute, University of Kansas, Lawrence, KS 66045, \\ USA (RMT) \\ Section of Mammals, Edward O'Neil Research Center, Carnegie Museum of Natural History, Pittsburgh, PA 15206, USA (SBM) \\ *Correspondent: btimm@ku.edu
}

Key words: American Society of Mammalogists, Annual Meetings, Board of Directors, Bylaws, history, mammal conservation, officers

If you want it done right, hire a mammalogist

Jim Findley (1980s)

James S. Findley (Past President, 1980-1982), long-time American Society of Mammalogists' (hereafter referred to as ASM or the Society) leader, and outstanding mentor and researcher, frequently remarked with the above succinct quote that captures the spirit of the Society-mammalogists are competent and committed. The ASM is one of the strongest taxonbased societies in the world. We have a dedicated, enthusiastic membership; our leadership is dynamic and forward thinking; we take strong, proactive, well-researched stands on conservation issues that we deem important and within our areas of expertise; and our journal is superbly run. Not coincidently, we have a significant endowment and carefully established spending policies that ensure the Society will continue to maintain the wide array of programs we have developed to support our students and the study of mammals. There are several keys to our success as a Society. Perhaps the most important component of the ASM's success is our history of strong leadership and management. Among our leadership's strengths is actively mentoring students, the future leaders of our Society. Although many scientists are good at "book-learning," leaders can usually credit their teaching and mentoring skills to the outstanding mentoring they received early in their careers. Common characteristics of most of the best leaders in the ASM's history include teaching by active example, working collaboratively with colleagues, creating opportunities for their students, and an unselfish, dedicated work ethic. In the last 25 years, leadership has become more widely distributed throughout the Society.

A second component to the ASM's success as an organization stems from our democratically organized and open management style. We operate under a well-defined set of bylaws that are updated regularly to adjust to the changing world.
We have a fair, welcoming management style that has been fostered by our leaders.

As the ASM is now celebrating its 100th anniversary, it is valuable to assess how the Society's management and leadership have evolved over the years and what aspects of our organization have served us best through the decades. Celebrating the ASM's major anniversaries with published compendia and reviews of history and science has been a long-standing tradition. Interesting, well-written, and informative chronological histories of the early years of the Society were provided by the ASM's first and long-time Historian Donald F. Hoffmeister (1959 - 40th anniversary of ASM, and 1969 - 50th anniversary; Fig. 1). As ASM Historian, Hoffmeister contributed an excellent series of short essays on the early history of the Society in the Journal of Mammalogy (hereafter referred to as the Journal) for the 75th anniversary celebration (Hoffmeister 1994a, 1994b, 1994c, 1994d).

In this chapter, we expand upon and update several sections on management provided by Hoffmeister and in the volume Seventy-five years of mammalogy (1919-1994) edited by Birney and Choate (1994), and we provide additional history and perspective on several of the topics discussed in other articles in this current compendium. Our goals are to review the ASM's history on leadership, management, and organization to better understand how the Society has evolved over the years, to succinctly explain the changing and expanding role of the officers and goals of our programs, and to document how the ASM operates in this current era.

\section{BYLAWS AND RULES}

Bylaws and Rules define the structure and function of an organization. From the very origins of the Society, there was recognition that even though the attendees at each Annual Meeting

(C) 2019 American Society of Mammalogists, www.mammalogy.org 


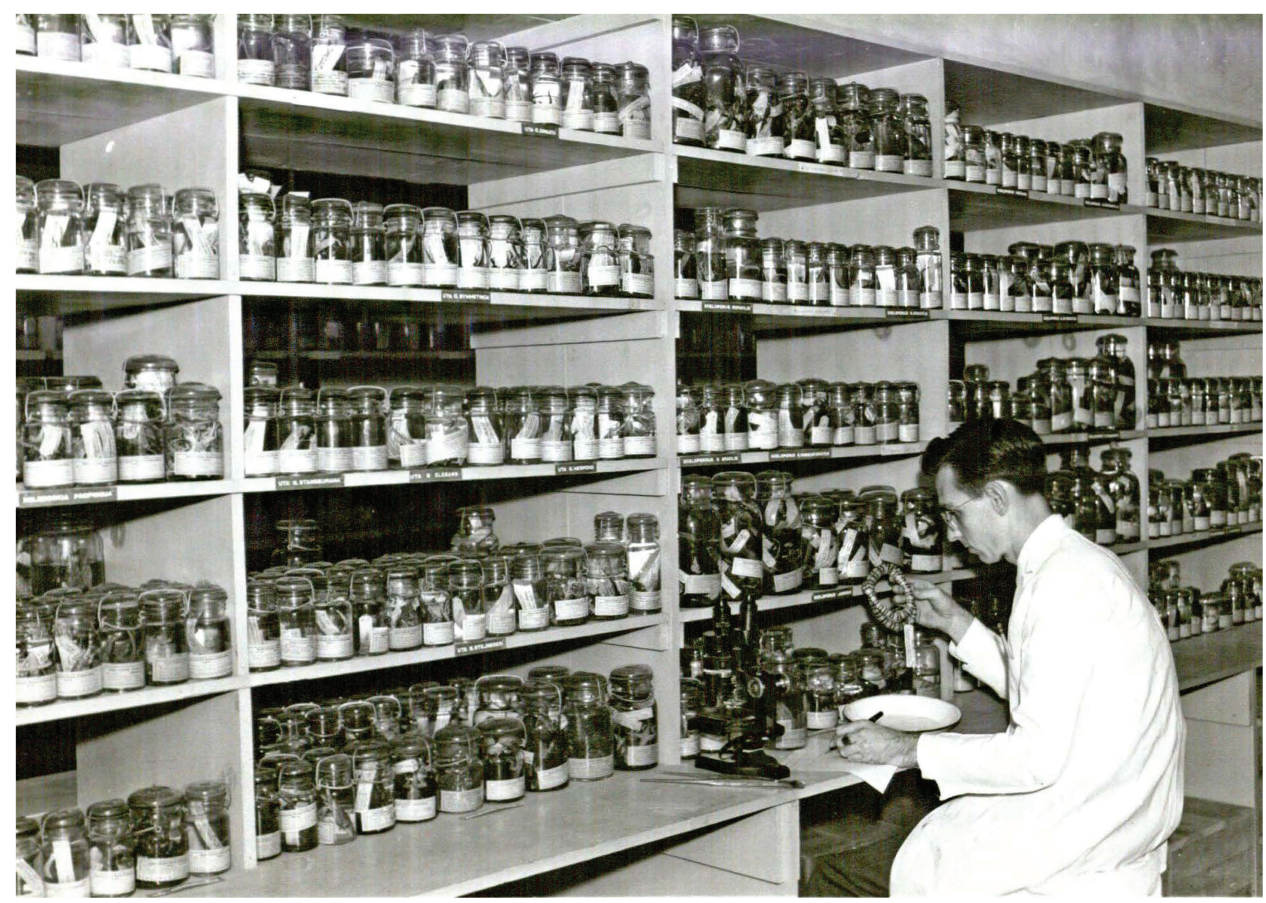

Fig. 1.-Donald F. Hoffmeister, then Curator of Mammals at the University of Kansas Museum of Natural History (1944-1946), sorting specimens in the museum. Additional details on Hoffmeister's life and accomplishments are provided by Schmidly (2012). Note the locally made wooden shelves and glass bail-top canning jars that were typical of fluid collection storage at the time. Image taken 1945. Courtesy of the Kenneth Spencer Research Library, University of Kansas Libraries (Accession 33/0).

would prefer to spend their time talking about mammals, it was important for the good of the organization to conduct structured discussions on how the ASM functions. Therefore, time is set aside each year for one or two meetings of the Board of Directors. Additionally, it was recognized that it is crucial to bring all the members in attendance at an Annual Meeting together to receive an overview of Board activities and to provide time for the election of officers and directors by the membership. This latter meeting was originally called a "Business" Meeting. However, to make it clear that all members were welcome and encouraged to attend and participate, in 1999 the word "Members" replaced the word "Business" with no change in the content of those meetings.

The philosophy behind the Society's election process acknowledges the fact that members who attend the Annual Meeting have a well-grounded understanding of the "business of the Society," and the tasks expected of the people who are being elected to each position, and are first-hand witnesses to how those duties are executed through activities that occur during the Annual Meeting. To ensure that Board and Members' Meetings are run efficiently, fairly, and collegially, ASM adheres to Robert's Rules of Order, the classic manual of parliamentary procedures.

Much of the ASM's business is now handled electronically. This has opened participation in Society business to a broader group of members, including international members, having the effect of increasing democracy. Online discussions and ballots also allow decisions to be made throughout the year in a timelier manner. The spirit of organizing and running a society such as ours remains the same- fair and inclusive decision-making by the group.
The ASM Bylaws are an evolving document and we strive to keep them relevant, using the document to make the Society a strong democracy. They state that proposed amendments are to be presented to the entire membership " 2 months" prior to a Members' Meeting to allow for active debate. New amendments require two-thirds approval by members attending an Annual Meeting.

The Articles of Incorporation and Temporary Bylaws were published in the Journal in 1923 (4:271-272), as adopted by the incorporators on 29 April 1920. However, the Bylaws and Rules were originally published in 1919 in the Journal (1:49-51), and have been amended 20 times over the decades since. Specific details of changes to the Bylaws are available in the published annual minutes of the Board and Members' (Business) Meetings, which are recapped in appropriate issues of the Journal. Regular updates of the Bylaws and Rules aim to make leadership more efficient and the Society more inclusive, recognizing the expanding role of women and welcoming student leadership. The current Bylaws and Rules (2018) are published in the Journal (99:1153-1557) as well as located on the Society's webpage (www.mammalogy.org/ asm-bylaws-and-rules).

In changing the Bylaws over the years, the Society made an effort to make rules of operation more flexible and inclusive. In 1984, the word "he" was changed to eliminate a gender-specific designation. Because of the strong editorial background of many of our members, wording revisions occurred throughout the document almost every time there was a revision based on more significant actions. Our Bylaws state "No substantial part of Society's activities will consist of carrying on propaganda or 
otherwise attempting to influence legislation, or of participating in any political campaign on behalf of any candidate for public office" (Article I, Sec. 3). However, the Society membership at an Annual Meeting may approve resolutions that provide wellresearched, scientific fact-based, carefully worded statements, regarding issues of the day that have an impact on the wellbeing of mammals.

\section{Changes in Society Management}

\section{Late 1990s Strategic Planning Process}

Following the 1996 Annual Meeting, President Alicia V. Linzey convened an ad hoc Strategic Planning Steering Committee, chaired by First Vice President O. James Reichman. This committee met twice over the next 2 years at the Smithsonian Institution's Conservation and Research Center in Front Royal, Virginia. Between these meetings, the committee members examined all aspects of ASM operations, and a number of significant changes were recommended to the Board of Directors. Among those implemented was the establishment of the position of President-Elect and the elimination of the position of Second Vice President. Another governance change was the addition of a student to each annually elected group of Directors-at-large serving 3-year terms, raising the total number of Directors-at-large from 15 to 18. Many of the changes approved by the Board required amendments to the Bylaws and Rules.

In 1998, President Reichman established an ad hoc Officers' Manual Committee to codify the roles of the OfficersPresident, President-Elect, Vice President (formerly First Vice President), Secretary-Treasurer, Recording Secretary, and Journal Editor. The responsibilities of the Past Presidents, Directors, Reserve Fund Trustees, Archivist, Historian, and Ombudspersons were also codified. The Officers' Manual was approved by the Board of Directors in 2003 and placed on the ASM website (American Society of Mammalogists 2003). A newly revised Officers' Manual is currently being assembled.

By the late 1990s, it became clear that the ASM's management style and budgetary process needed to be modernized. Historically, annual dues, for example, were raised based mostly on what was needed to cover the past year's and current bills with little thought of planning for future expenses, the primary one being the printing and mailing costs for the Journal (Kirkland and Smith 1994). An important recommendation in the Strategic Plan was the establishment of the Planning and Finance Committee to be chaired by the President-Elect. This committee was charged with developing a budget that allows the Society to set goals for what we wish to accomplish and provides for funds to accomplish those goals upon Board approval. Additionally, the ASM can now provide financial assistance to sister organizations such as the International Federation of Mammalogists and newly emerging mammal societies throughout the world that need help getting started (see Álvarez-Castañeda et al. 2019 for a summary of the ASM role in internationalization of mammalogy).

\section{The Changing Roles of ASM Leaders}

As observed in the 75th Anniversary volume (Birney and Choate 1994), ASM presidents have generally risen through the ranks within the Society, serving on committees, as committee chairs, directors, and other officers before becoming President. That is still true today (Merrick and Wilson 2019). These experiences provide an important perspective on the wide array of tasks the President is expected to oversee while in office and provides members an opportunity to observe the capabilities and temperament of prospective leaders. Encouraging student participation in committee activities is a vitally important step to ensure a fresh infusion of ideas, to inspire new members to continue their membership as part of a network of scientists interested in mammal research, and to cultivate the next generation of leaders of the ASM (McDonough et al. 2019). A complete listing of all officers who have served the Society since its inception in 1919 is provided on the Archives Committee's webpage (www.mammalogy.org/committees/archives\#tab4, accessed 23 November 2018).

President.-The President is responsible for the successful operation of all aspects of the Society's management (American Society of Mammalogists 2003). This officer is expected to oversee and expedite the work of the other officers, the quality and timely production of the Society's publications, and its website. Presidents represent the Society to all those outside the organization, attending meetings and providing official responses to inquiries, requests, interviews, and public issues. The President serves as the arbiter of last resort for all matters including those involving authors of Society publications and appoints the chairs of all committees except the Honorary Membership Committee. The President recommends an ASM member to fill the role of Publications Director, who chairs the Publications Advisory Board, and the Program Director, who chairs the Program Committee, and these recommendations are approved by the Board of Directors. Finally, Presidents approve the appointment of committee members except for the members of the Publications Advisory Board, who are nominated by the Publications Director and approved by the Board of Directors. It is the President's duty to oversee, encourage, and solve problems encountered during the course of each committee's work. The President may organize, charge, and discharge ad hoc committees as needed in the conduct of Society affairs. At the Annual Meeting, the President presides over two Board Meetings as well as two Members' Meetings during which voting for Officers and Directors-at-large is conducted. It is also the President's role to open the Annual Meeting and to chair the first plenary session, which involves discussion of mammal research. He or she also officiates over any Society business conducted at the banquet or the closing ceremony of the Annual Meeting.

With the advent of the internet in the early 1990s, the nowubiquitous use of e-mail communication between officers, committee chairs, and members became fast and easy, facilitating committee work, and enabling ASM to conduct Board business of all kinds in a timely manner. Rapid communication also assists the President in the role of mentoring the 
President-Elect. Electronic communication has streamlined the collection of annual reports, which is now carried out by the Coordination Committee. This committee receives and compiles all committee reports, the comprehensive reports of the Secretary-Treasurer and the Trustees, and the proposed annual budget into a document informally known as "the Board Book." This document is distributed by the President to Board members and made available online in preparation for the Annual Meeting.

While the types of duties expected of the President have remained the same in the last 25 years, the volume of work has increased, principally due to an increase in the number of committees, the diversity of committee activities, the creation of additional awards (see Heske and Bell 2019), the need to provide mechanisms for student support, and the increased budget. It is no small feat to intimately know the role of each of more than 30 committees, to find the right individual to successfully chair each committee, and to oversee the membership of each committee. The annual task of appointing members to committees begins after each Annual Meeting and can continue for several months until each committee's makeup is complete. As an organization that is run primarily on the efforts of volunteers, choosing the right individuals to fulfill the duties of a committee is not always easy. For example, the Grants-in-Aid Committee carries the responsibility of reviewing more than 100 research proposals each year for student grants; in recent years the committee has overseen the granting of more than $\$ 72,000$ for graduate and undergraduate student research. The Chair must distribute proposals among the committee's membership for review and award available grants-in-aid of research funds to nearly 40 students every year, as well as two fellowships on a strict timetable. In the last 25 years, the African Graduate Student Research Fund Committee and the Latin American Fellowships Committee (which oversees the Oliver P. Pearson Award) have been added and have taken on expanding roles. The Conservation Award Committee now recognizes both a student and a senior researcher for contributions to the conservation of mammals through the William T. Hornaday and Aldo Leopold awards, respectively. The Joseph Grinnell Award Committee recognizes excellence in teaching and mentoring. The James L. Patton Award promotes and supports museum-based research by graduate students. The Student Science Policy Award provides graduate students with experience in the realm of science public policy in collaboration with the American Institute of Biological Sciences (AIBS) in Washington, D.C. The Honoraria Committee has expanded its title and responsibilities to the Honoraria and Travel Awards Committee, and both honors graduate students for their research in mammalogy and awards travel funds for students, including undergraduates, to attend Annual Meetings. Each committee's work relies upon careful timing and teamwork to complete its responsibilities and report on its success in preparation for the Annual Meeting.

President-Elect.-The establishment of the office of President-Elect has provided greater stability and knowledge in the leadership of the Society. It provides a 2-year "training" period for the myriad duties of the presidency during which the identity of the incoming president is known. Being able to transfer the knowledge needed to work with this all-volunteer organization over the course of 2 years ensures that the momentum of its work can continue as leadership changes. A major duty of the President-Elect is to chair the Planning and Finance Committee as it develops an annual budget. During this process, the Committee works closely with the Secretary-Treasurer and the President. The President-Elect presents the draft budget to the Board during the first Board Meeting. The effort creating this budget ensures familiarity with the tasks of many committees as well as an understanding of the Society's revenue streams and its endowments. In the event of the absence of the President, the President-Elect must fulfill that role, so knowledge of management, operations, and publication activities of the Society is critically important. The role of President-Elect ensures that the new person already understands a great deal of the details of Society business. Finally, the expansion of awards has necessitated the addition of a second plenary session to the Annual Meeting. It is now the role of the President-Elect to chair this session, which features talks from the Grinnell, Leopold, and Merriam awardees.

Vice President.-The Vice President must be prepared to step into the position of President-Elect and even the presidency in the absence of one or both of those officers. The one established duty of the Vice President is to arrange for a speaker to give the final presentation of the Annual Meeting, which is to be of broad interest. The Vice President selects the speaker and coordinates the speaker's attendance with the Program Committee. This officer may also be assigned other duties by the President or the Board of Directors.

Secretary-Treasurer-The Secretary-Treasurer plays an important role in developing the proposed annual budget, handling membership issues, and providing oversight of the approved budget. This role has undergone a number of changes over the years. When this position was created in 1957, the Secretary-Treasurer became the chief liaison between the Society and individual members, working with an ever-growing number of members that eventually exceeded 4,000 plus several hundred library subscriptions. Bryan P. Glass served as the Society's first Secretary-Treasurer (1957-1977) and was assisted by his wife Carolyn. In 1977, the information technology staff at Carnegie Museum of Natural History assisted with the transition of the Secretary-Treasurer's position from Bryan Glass to Duane A. Schlitter by facilitating computerization of the membership list and financial management of the Society's accounting system (D. A. Schlitter, personal communication). Furthermore, between 1977 and 2001, the Society formalized the assistance given by the spouse of the SecretaryTreasurer by providing remuneration for a "bookkeeper." This arrangement began with Duane Schlitter and his wife Judith (1977-1980), followed by Gordon L. Kirkland, Jr. and his wife Carol (1980-1986), and finally with H. Duane and Dahnelle Smith (1986-2001). In 2002, the Society signed a contract with Allen Marketing and Management, a subdivision of Allen Press (Lawrence, Kansas) for "Executive Level Services" to work in 
close collaboration with the newly elected Secretary-Treasurer Ronald A. Van Den Bussche. This contract was undertaken as a separate arrangement from the printing contract with Allen Press. In 2014, the Society sought a bid for management services from Christy Classi (Topeka, Kansas), a former staff member at Allen Press. Because her newly formed business (Classi Management Services, LLC) and knowledge of the Society was a good fit, ASM approved a management agreement with her at the close of the 2009-2014 contract with Allen Marketing and Management.

Recording Secretary.-The Recording Secretary is responsible for creating a written record of all Society meetings, including electronic communications and votes that are held in the interval between Annual Meetings. This documentation is made available to the Board of Directors in both abridged and unabridged form, as well as to the membership through the Journal and the Archives. Prior to each Annual Meeting, the Recording Secretary arranges for electronic recording of both the Board and Members' Meetings, and captures information on all awards that are announced during the formal meetings and at the banquet or closing ceremonies. The Recording Secretary also gathers a record of attendees at the Board Meetings and maintains the current list of contact information for all Officers and Directors. The Recording Secretary provides the appropriate information from the Annual Meetings to the Editor-inChief for publication in the back of the Journal, including, from the Resolutions Committee, resolutions that the membership had approved. Unlike the serious nature of most resolutions, the Host Resolution is a playful recounting of occurrences over the course of the Annual Meeting, from a detail about a talk during the plenary sessions to especially notable efforts on the part of the host institution. This homage to a shared week of committee meetings, talks, posters, symposia, and workshops culminates in a tribute to our host institution for their considerable efforts at putting on a successful meeting.

Publications Director-Following the Bylaws amendments in 1999 and the 2000 contract with Allen Press, the duties of the Managing Editor of the Journal were transferred to Allen Press and hence the Managing Editor was no longer an ASM member. As the second 5-year contract with Allen Press drew toward a close, the then-Chair of the Publications Committee (Douglas A. Kelt) chaired an ad hoc committee that worked with an outside consultant to reevaluate our publication needs and consider bids for a new contract. The result of this effort led ASM to select Oxford University Press (OUP), which became its new publisher in 2015. A change in the Bylaws in 2013 replaced the Chair of the Publications Committee with a Publications Director who would chair the Publications Committee, renamed the Publications Advisory Board, and replace the Journal Editor as an officer. The duties of the Publications Director include overseeing all Society publications, identifying editors for those publications, helping maintain quality publications, working with editors to develop policy related to publications, and serving as the primary liaison, on behalf of the Board, with the publisher of the Society's publications. Kelt was the first Publication Director. In mid-2013, the title "Journal Editor" was changed to Editor-in-Chief with the same duties as originally specified in the Officers' Manual (complete responsibility for all content that appears in the Journal).

Program Director--In 2017, the Bylaws were amended to add a Program Director as a new Officer of the Society who is responsible for planning and executing the Annual Meetings and serves as Chair of the Program Committee. Cody W. Thompson became the first Program Director, having worked closely for several years with Kansas State University's Convention Services to organize our meetings.

Past Presidents.-Past Presidents are members of the Board of Directors for life, and frequently an individual Past President is asked by the current President to take on special assignments. Traditionally, but not identified in the Bylaws, the most recent five Past Presidents make up the Honorary Membership Committee, which nominates candidates for Honorary Membership. The second-most senior member of that group serves a 2-year term as Chair of the Honorary Membership Committee.

Board of Directors.-The Board of Directors is made up of the Officers, Past Presidents, Chair of the Trustees, and 18 individuals who are elected specifically as Directors-at-large. Directors-at-large are nominated and elected during the Annual Meeting for 3-year terms. Those who nominate a member to serve as a Director-at-large must write a short biographical statement following the first Members' Meeting and post it on available bulletin boards, so that voters can review the information on all nominees before voting at the second Members' Meeting.

The Board of Directors appoints the Secretary-Treasurer and elects the Program Director and Publications Director, as well as editors nominated by the Publications Director. They appoint Trustees for the Reserve Fund and the Pooled Income Fund annually who serve, on a rotating basis, a 3-year term, with no limit on terms for reappointment. The Board is empowered to temporarily fill vacancies among the Officers and Directors-atlarge by appointment. Financial matters overseen by the Board include adopting an annual budget and approval of the use of the Reserve Fund to conduct the business of the Society as necessary. The Board of Directors sets annual dues for members, as well as the cost for Student, Life, and Patron memberships, and takes action with regard to members in arrears of dues. Directors approve how funds received from Life and Patron memberships, as well as gifts to the Reserve Fund, are expended. They consider terms and conditions to bequests and trusts before acceptance by the ASM and report those actions to the membership. Directors may consider spending to promote global interactions among mammalogists, such as funding to support international congresses. In the event of the dissolution of the Society, it is the Board of Directors who would determine the "distribution of the assets and accumulated income for such charitable, scientific, literary, or educational purposes as in their judgment qualify" under the provisions of the Internal Revenue Code. Directors make policy and provide advice to the President. They review the annual report of the SecretaryTreasurer, including an audit, at the Annual Meeting. They 
receive reports from the standing and ad hoc committees and approve or advise on action items and activities of these committees. Directors decide the location of an Annual Meeting if no decision is made by members or in case of an emergency. Directors may recommend amendments to the Bylaws and Rules that can be adopted by a two-thirds vote of the members at an Annual Meeting. Nominees to receive the Joseph Grinnell Award, the Hartley H. T. Jackson Award, the Aldo Leopold Award, and the C. Hart Merriam Award are submitted to the Board for approval before the honor is bestowed. Upon recommendation by a majority of the Directors, in recognition of extremely distinguished careers in mammalogy, Honorary Membership in the ASM is bestowed upon an individual after a vote of the membership at an Annual Meeting. The Board may establish awards for students, such as the William T. Hornaday Award, that support or recognize contributions to outstanding achievements in mammalogy. Directors recommend and elect an individual for Patron membership and they approve a member's request for Emeritus membership. Beginning in 1999, in addition to the five Directors-at-large who are elected for 3-year terms during each Annual Meeting, the membership began nominating and electing a student member for a 3-year term.

Trustees.-The Trustees of the Reserve Fund and Pooled Income Fund protect and manage these funds of the Society in a manner to obtain optimal performance in a diversified portfolio of stocks, bonds, mutual funds, and cash instruments. It is the Trustees' responsibility to increase the value of the Reserve Fund to provide revenue for support of programs and publications that enhance the science of mammalogy and the training of mammalogists, and to provide accurate and current information and recommendations regarding the Reserve Fund to the Board so that body can make the most informed financial decisions possible on behalf of the membership. The Chair of the Trustees is a voting member of the Board.

The Pooled Income Fund was a new investment established in 1998 with an initial market value of $\$ 10,206$ as an investment option for donors who wish to contribute to the ASM and obtain a tax advantage for doing so while continuing to receive income from their contributions. At the end of each calendar year, the Trustees disperse that year's interest and dividend income to the shareholders (donors) in the Fund in proportion to their percentage ownership. Upon death of a shareholder, his or her percentage of the Fund is transferred to the Reserve Fund.

Archivist.-The ASM Archivist is a member of the Society who serves on the Archives Committee and works with the Smithsonian Institution Archives (SIA) staff to ensure that appropriate ASM documents are permanently retained in appropriate conditions on behalf of the Society. The documents that the Archivist seeks to add to the archives have been designated by the Board and include: publications, including special reports and documentation; financial reports; trustees' reports; officers' correspondence; board members' correspondence; committee correspondence and reports; editors' correspondence (except correspondence soliciting reviews and old manuscripts); photographs of ASM activities and any mammalogically important activities; résumés of officers, editors, board members, Honorary Members, and awardees; and photographs of presidents, Honorary Members, and awardees. The Archivist coordinates with researchers to ensure appropriate access to the Society's archives. Our documents are professionally managed by SIA under written agreement (ASM's archives are available at 600 Maryland Ave. SW \#3000, Washington, DC 20024, and include more than 162 boxes of materials and four oversized folders. A useful link to aid in finding records is provided: https://siarchives.si.edu/collections/siris_arc_217513).

Historian.-The Historian works with the Archivist as the only other specifically designated member of the Archives Committee and is the chair of the committee. The Historian ensures that the documents delineated above are obtained and sent to the Archivist for the Society's archives. The Historian solicits résumés and photographs from presidents, Honorary Members, and awardees. The Historian is responsible for keeping a photographic record of the activities of the ASM and will work with members to obtain photographs taken by other members of the Society. From time to time, the Historian can publish articles in the Journal elucidating the history of mammalogy and of the ASM. The Historian submits a written annual report to the Board of Directors before each Annual Meeting on behalf of the Archives Committee.

Ombudspersons._At the 1993 Annual Meeting, the ad hoc Committee on Women and Minority Issues suggested establishing an "ombudsman" program to provide an avenue whereby ASM members and meeting participants can air complaints about discriminatory or harassing behaviors within the Society. At the 1994 Annual Meeting, President Patton announced that he had established an ad hoc watchdog to be known as the ASM Ombudsperson to hear and respond to complaints of unprofessional behavior by any member of the Society at its Annual Meeting or in the governance of the Society through its committee structure. Sarah B. George and Richard W. Thorington, Jr. were appointed by Patton as the first Ombudspersons. Subsequently, Felisa A. Smith replaced George and served for nearly 25 years alongside Thorington. The role of the Ombudspersons is to serve as an arbitrator for member concerns with an emphasis on confidentially. As an ad hoc entity, the President appoints the members. Since its inception, two senior members have served simultaneously as Ombudspersons, with no chair appointed. In 2018, the Society implemented a policy on professional conduct (www.mammalogy.org/committees/office-ombudsperson\#tab2, accessed 22 November 2018).

Standing and ad hoc committees.-Two types of committees are defined in the Bylaws. Standing committees perform most of the functions of the Society; the Chair and all committee members are appointed by the President, with three exceptions previously noted. Ad hoc committees can be established to address a specific issue and are formed at the discretion of the President or by a majority vote of the membership in attendance at a Members Meeting. Ad hoc committees cease to exist when their charge is completed, or as determined by the President. 
The Chair of each committee reports on their activities at each Annual Meeting.

\section{IRS Regulations And ASM Policies}

In 2009, the U.S. Internal Revenue Service (IRS) required the implementation of new policies including some management functions-Document Retention, Conflict of Interest, Ethics, and an Investment Policy and Procedures. The Officers drafted all four policies, which were approved by the Board of Directors at the 2009 Annual Meeting. The four policies were communicated to the IRS immediately following that meeting and are posted on the ASM website (American Society of Mammalogists 2009a, 2009b, 2009c, 2009d).

In order to avoid grants to students being considered taxable income, award funds are sent to the students' home institution. To insure that all award funds are available to the student for their research, a policy addressing indirect costs was instituted by the Board in 2017. This policy states that the Society will not pay indirect costs associated with modest awards disbursed to advance mammalian research, thus preserving the entire award for its intended purpose; the policy is posted on the ASM website (American Society of Mammalogists 2017).

\section{From Printing to Publishing Partnerships and Management}

The Journal was first printed by the Williams \& Wilkins Company of Baltimore, Maryland, which later changed its name to Waverly Inc. It was the only firm to provide a bid for publishing the new journal in 1919, and Waverly continued to print the Journal through 1955. Beginning in 1956, the ASM and Allen Press of Lawrence, Kansas, developed a close working relationship that lasted for 60 years (1956-2015), and evolved from Allen Press being the printer to being a publishing and business partner in 2009; Allen Press started publishing the Journal in 1957 (volume 38). Allen Press originally just printed and mailed the Journal and other business jobs that were printed for the ASM. Over the years, the business relationship grew to their serving as copublisher and distributor of all of ASM's publications, a relationship that involved revenue sharing as well as many tasks undertaken previously by our unpaid volunteers. The company added back issue warehousing, order fulfillment, and mailing list services. In 2015, the Society contracted with OUP (Oxford, United Kingdom) to publish and distribute both the Journal and Mammalian Species. OUP services include copyediting of the scientific papers, printed and electronic access to ASM publications, and archival copies of Mammalian Species to designated libraries. OUP provides marketing of ASM publications and membership.

The Society's publications have been a centerpiece of ASM activities since its inception (Verts and Birney 1994; Leslie and Hamilton 2019). Even the earliest issues of the Journal were substantive publications. The production of publications has always been a particularly stellar example of the selfless spirit of volunteerism that keeps the Society functioning year after year. Even during World War II, when so many members were involved in the war effort and rationing made holding an Annual Meeting problematic, research was conducted, papers were written and reviewed, and the Journal continued to be published. In 2003, the Journal expanded to a larger format with six issues instead of four, increasing from 1,200 to 1,600 pages per year. Most scientific journals were being encouraged by printers to expand page size to $81 / 2 \times 11$ inches, as the larger size minimized paper costs and thus provided considerable financial savings; it also allowed the societies to take better advantage of article formatting options. Keeping six issues of the Journal on schedule issue after issue requires careful management by several Associate Editors and the Editor-in-Chief. Because of the committed membership, the Society has always been fortunate to find new people to step forward and serve as editors.

\section{Changing Membership and Revenue STREAMS}

The ASM is an international society and has been since its beginning. The first listing of members, published in the Journal in 1920, included 358 individuals from 15 countries; of these $13 \%$ were from outside of the United States-from Australia (1), Brazil (2), British Papua (= Papua New Guinea, 1), Canada (24), Costa Rica (1), Cuba (1), Denmark (2), England (3), France (2), Germany (1), Holland (1), Ireland (1), Spain (1), S. Africa (2), and Sweden (2), in addition to the United States including the territory of Porto Rico [sic] (1), with 346 regular, 11 life, and 1 honorary member (Hollister 1920a). By 1922, there were 555 members with 19 countries outside of the United States being represented. Today there are approximately 2,400 members from 78 countries. The ASM actively seeks to promote international memberships with programs in place to make access to our publications affordable. Online memberships are available at a reduced rate, because the cost of shipping the Journal is eliminated. Society members may serve as sponsors for other individuals through a sponsorship program managed by the International Relations Committee. For more detail about the Society's international involvement, see Álvarez-Castañeda et al. (2019).

The role of women and their representation in the Society's membership has steadily increased. The photograph taken of attendees at the organizational meeting of the Society in 1919 shows 14 women and 43 men (see Hoffmeister and Sterling 1994; Genoways and Freeman 2001; www.mammalogy.org/ uploads/ASM_4April1919.jpg). Of the original 358 members, we identified 16 names as representing female members. Reflecting the increasing role of women in our science and in advanced education, at the 2018 Annual Meeting in Manhattan, Kansas, females comprised $42 \%$ of those registered.

Although few in number in the early years of the Society, several women played active leadership roles in the field, including Annie M. Alexander, Caroline A. Heppenstall, Anna M. Jackson (see below), and long-term treasurer (1930-1953) Viola S. Schantz. On the West Coast, Annie Alexander was 
the first woman Life Member and founder of the Museum of Vertebrate Zoology (MVZ), University of California, Berkeley (Stein 2001).

The participation of women in leadership roles has increased steadily over the decades in all aspects of the Society. A Special Feature on the changing role of women in North American mammalogy appeared in the Journal in 1996 (77:609-674). Smith and Kaufman (1996) documented that for the first 75 years the percentage of women serving on committees varied considerably, with committees oriented toward education and outreach being most frequently represented. They also observed that the percentage of women receiving grants-in-aid increased significantly. Bibliographic summaries of women's lives and accomplishments were provided in the Special Feature articles by Kaufman et al. (1996) and Stein (1996), and personal perspectives of working in the field of mammalogy was provided by Horner et al. (1996). Genoways and Freeman (2001) documented the changes and expansion of the presentations and the increasing role of women at the Annual Meetings. Dizney et al. (2019) summarize the Society's historical and recent membership, including participation and efforts to create a more welcoming environment for women and minorities.

Like all taxon-based societies, the ASM experienced a decline in membership beginning in the early 2000s. The reasons for this were multifold including a shift from organismal to discipline-based approaches in the universities and new technology providing online access to publications including the Journal and Mammalian Species. The associated loss of revenue necessitated changing approaches to financial management, more attention to recruitment and retention of new members, and a concerted effort to make our Annual Meetings more welcoming and interesting to a broader group.

The shift by university libraries to electronic subscriptions inevitably led to a significant loss in revenue from publication sales; the ASM had relied on library subscriptions for nearly one-fourth of its annual revenue. Libraries turned to subscribing through "aggregators," who packaged multiple journal subscriptions, rather than working directly with scientific societies. Allen Press responded by working with several aggregators to stem the tide of their and our revenue loss. Two aggregators, BioOne and JSTOR, were early collaborators with the Society, providing much needed revenue and ready access throughout the world to our publications. The ASM (through AIBS) was one of the first founding societies to work with BioOne, a collaboration between AIBS, Allen Press, SPARC - the Scholarly Publishing and Academic Resources Coalition, the Greater Western Library Alliance, and the University of Kansas, to provide societies with revenue from library use (https:// en.wikipedia.org/wiki/BioOne, accessed 22 July 2018).

The burgeoning influence of the internet has opened new avenues for communicating the science of mammalogy, the importance of mammals worldwide, educating a broader audience, and highlighting research and conservation issues. Using social media as a rapid means of education and marketing, a wide array of topics are communicated to ASM members and the public at virtually no cost. Our current participation in social media includes Facebook (https://www. facebook.com/American.Society.of.Mammalogists); Twitter (@Mammalogists); LinkedIn (http://www.linkedin. com/groups/American-Society-Mammalogists-4575484); Instagram (@amersocmammalogists); YouTube (https://www. youtube.com/channel/UCA6tp7M-8d9YFLorYysHR_Q); and Google+ (https://plus.google.com/\#s/american\%20society\%20 of $\% 20$ mammalogists67). Aspects of Annual Meetings are now available via the internet, including online abstracts and videos of the major presentations accessible through streaming. The addition of a meeting app allows access to the entire program, including the ability to earmark events on a personal schedule and receive reminders about talks, posters, committee meetings and other activities throughout the Meeting. This has eliminated excess printing costs and made it possible for those who are not able to attend the meetings to have a close look at the program as well.

\section{OUTGROWTHS OF LEADERSHIP}

ASM members are leaders of science, education, and conservation of mammals worldwide. From our earliest days, the first editor of the Journal, Ned Hollister, wrote condemning "any cruelty or acts of negligence in the care of animals" (Hollister 1920b:252). Hollister, earlier, expressed the concern among mammalogists for the extinction of furbearers because of widespread overharvest. The demand for furs was so high in 1920 that 1,121,000 raw furs were on sale in New York fur markets that year. Even striped skunk skins (Mephitis mephitis) were selling for $\$ 12.50$ with 239,000 individuals being handled in that 1 year (Hollister 1920c). Similarly, C. Hart Merriam, the first ASM president, also founded the U.S. Biological Survey, which focused primary on mammals and birds. When Merriam retired, the Survey became an agency whose primary function was to support the western livestock industry in controlling predators (Schmidly 2016; Baird et al. 2019; Schmidly and Naples 2019). Another leading ASM member, E. Raymond Hall at the University of California and later at the University of Kansas in Lawrence, was an active spokesperson against the official federal government's practice of broad scale trapping and poisoning of predators and ground squirrels throughout the West and testified before Congress on the value of predators (Graham 1986). The well-funded predator control programs were largely discontinued in the 1970s (Robinson 2016); however, the persecution of predators was so persistent and effective that wolves (Canis lupus) were extirpated from the western United States. Today, the Society is even more actively involved with conservation issues with members publishing papers on their research and ASM committees proposing well-researched statements to decision makers and resolutions on specific conservation issues.

\section{Conclusions}

Late in 1918 after one of the early organizational meetings to form a society dedicated to the study of mammals, Hartley 
H. T. Jackson's wife, Anna Jackson, was "pressed into service to gather much of the necessary data. Hartley rented her a typewriter, typing desk, and chair for use in their apartment" (Hoffmeister 1994a:i). Thus, the American Society of Mammalogists started from very humble beginnings with rented equipment, furniture, and volunteer staff.

Over the past century, the ASM evolved from that small, allvolunteer, primarily male-run organization to the leading international society that is the active leader in the dissemination of information about, and conservation of, the world's mammals. International representation has always been strong. The Society was founded with $13 \%$ of the members residing outside of the United States and today 78 countries are represented in the membership. From an inauspicious beginning, women now play important roles in all aspects of Society leadership. We now recognize Anna Jackson's accomplishments and leadership with one of our major student awards. Four women have served as President of the Society, and numerous others are officers and committee chairs. Student members are active participants on committees and hold three Board positions.

From the Society's founding in 1919 until the 1990s, member volunteers ran all aspects of Society business and a commercial printer was paid to print the Journal. Now a close collaboration between our member volunteers and experienced, professional management, together with a world-class publisher, handle some aspects of our business. A testament to the decades of volunteer efforts that contributed to the Journal is evidenced by it being named in 2009 as one of the top 100 most influential journals in biology and medicine in the past century by the Special Library Association's BioMedical and Life Sciences Division.

One of the keys to the Society's success is strong member participation by committed, generous mammalogists. Students in the various universities, colleges, and museums are often introduced to the ASM and mentored by dedicated, experienced mammalogists on the staff, allowing the students to learn the culture of the Society as well as the science. Most of our leaders got their start in the Society through strong mentorship. Our Bylaws are kept current to accommodate the changing academic and political world of the 21st century. Meetings are constructive and collegial. Our leadership operates under the motto that good leaders need to think critically but thinking critically is also thinking creatively.

Shortly before his death in 1988, our founder Hartley H. T. Jackson wrote to then ASM Historian Hoffmeister that, "There is no event that I would rather attend than the 50th Anniversary Celebration of The American Society of Mammalogists, unless possibly it would be the 100th anniversary ... I'm sorry I cannot be with you in person, but I am in spirit" (Hoffmeister 1994a:ii). Yes, Dr. Jackson you are here with us in spirit, and that fledgling group of mammalogists that you and Anna worked so hard to organize in 19181919 is very much alive and stronger today than it has ever been because your efforts.

\section{ACKNOWLEDGMENTS}

Our advisors, Elmer C. Birney and Gordon L. Kirkland, Jr., got us involved in ASM activities early in our graduate careers and we are grateful for their patience, trust, rigor, attention to detail, and exemplary work ethic-they were truly unselfish leaders of the Society. Our "surrogate advisors" H. H. Genoways and D. A. Schlitter taught us the history and mechanics of getting ASM business done. We thank B. L. Clauson and A. W. McLaren for their decades of assistance, tolerance of our long hours spent working on ASM business, and willingly allowing us to use significant family financial resources for our work for the ASM. D. Bridge, V. Hayssen, and T. J. McIntyre shared their knowledge of ASM history with us, significantly contributing to the details presented here. B. H. Blake, E. J. Heske, D. M. Leslie, Jr., and A. V. Linzey and an anonymous reviewer critically reviewed earlier drafts of this manuscript, considerably improving it. M. G. Girard's masterful efforts in improving the figure used herein are most appreciated.

\section{Literature Cited}

Álvarez-Castañeda, S. T., C. A. Segura-Trujillo, and W. Z. Lidicker, JR. 2019. Impact of the American Society of Mammalogists on the internationalization of mammalogy. Journal of Mammalogy 100:751-762.

American Society of Mammalogists. 2003. American Society of Mammalogists: duties and responsibilities of the officers of the Society. www.mammalsociety.org/uploads/ASM\%200fficers $\% 20$ Manual\%202003.pdf. Accessed 15 July 2018.

American Society of Mammalogists. 2009a. American Society of Mammalogists: conflict of interest policy. www.mammalsociety. org/uploads/ASM\%20Conflict\%20of\%20Interest.pdf. Accessed 15 July 2018.

American Society of Mammalogists. 2009b. American Society of Mammalogists: document retention and destruction policy. www.mammalsociety.org/uploads/ASM\%20Document $\% 20$ Retention\%20Policy.pdf. Accessed 15 July 2018.

American Society of Mammalogists. 2009c. American Society of Mammalogists: ethics policy. www.mammalsociety.org/uploads/ ASM\%20Ethics\%20Statement.pdf. Accessed 15 July 2018.

American Society of Mammalogists. 2009d. American Society of Mammalogists: investment policy. www.mammalsociety.org/ uploads/ASM\%20Investment\%20Policies\%20and\%20Procedures. pdf. Accessed 15 July 2018.

American Society of Mammalogists. 2017. ASM's policy on indirect costs for grants and awards. www.mammalogy.org/uploads/ ASM_IndirectCostsPolicy.pdf. Accessed 23 November 2018.

Baird, A. B., M. J. Robinson, AND J. R. Bickham. 2019. The role of the American Society of Mammalogists in mammalian conservation: from politics to conservation genetics. Journal of Mammalogy 100:774-785.

Birney, E. C., AND J. R. Choate (eds.). 1994. Seventy-five years of mammalogy (1919-1994). Special Publication 11, American Society of Mammalogists, Lawrence, Kansas.

Dizney, L., J. KarR, and R. J. Rowe. 2019. The contribution and recognition of women in the field of mammalogy. Journal of Mammalogy 100:678-689.

Genoways, H. H., and P. W. Freeman. 2001. Evolution of a scientific meeting: eighty annual meetings of the American Society of Mammalogists, 1919-2000. Journal of Mammalogy 82:582-603.

Graham, F., JR. 1986. Hall's mark of excellence. Audubon 86:88-102.

Heske, E. J., And K. C. Bell. 2019. ASM professional awards. Journal of Mammalogy 100:668-677. 
Hoffmeister, D. F. 1959. A chronological history of the American Society of Mammalogists. Journal of Mammalogy 40:276-277.

Hoffmeister, D. F. 1969. The first fifty years of the American Society of Mammalogists. Journal of Mammalogy 50:794-802.

Hoffmeister, D. F. 1994a. Hartley H. T. Jackson and the American Society of Mammalogists. Journal of Mammalogy 75:i-ii.

HoFFMEISTER, D. F. 1994b. C. Hart Merriam: "Father" of the organizers of the American Society of Mammalogists. Journal of Mammalogy 75:i-ii.

Hoffmeister, D. F. 1994c. The importance of the United States Bureau of Biological Survey in the formation of the American Society of Mammalogists. Journal of Mammalogy 75:i-ii.

Hoffmeister, D. F. 1994d. The influence of university and museum professionals in the formation of the American Society of Mammalogists. Journal of Mammalogy 75:i-ii.

Hoffmeister, D. F., AND K. B. STERLING. 1994. Origin. Pp. 1-21 in Seventy-five years of mammalogy (1919-1994) (E. C. Birney and J. R. Choate, eds.). Special Publication 11, American Society of Mammalogists, Lawrence, Kansas.

Hollister, N. 1920a. List of members of the American Society of Mammalogists. Journal of Mammalogy 1:201-212.

Hollister, N. 1920b. Editorial comment. Journal of Mammalogy $1: 250-252$.

Hollister, N. 1920c. Editorial comment. Journal of Mammalogy 1:159-160.

Horner, B. E., J. M. Taylor, A. V. Linzey, and G. R. Michener. 1996. Women in mammalogy (1940-1994): personal perspectives. Journal of Mammalogy 77:655-674.

Kaufman, D. M., D. W. Kaufman, and G. A. Kaufman. 1996. Women in the early years of the American Society of Mammalogists (1919-1949). Journal of Mammalogy 77:642-654.

Kirkland, G. L., JR., AND H. D. Smith. 1994. Membership and finance. Pp. 171-177 in Seventy-five years of mammalogy (19191994) (E. C. Birney and J. R. Choate, eds.). Special Publication 11, American Society of Mammalogists, Lawrence, Kansas.

Leslie, D. M., JR., AND M. J. Hamilton. 2019. ASM publications. Journal of Mammalogy 100:656-667.

McDonough, M. M., N. S. Upham, and A. W. Ferguson. 2019. Nurturing the generations: the role of the American Society of
Mammalogists in supporting students and early career scientists. Journal of Mammalogy 100:690-700.

Merrick, M. M., AND D. E. WiLson. 2019. ASM presidents. Journal of Mammalogy 100:627-645.

Robinson, M. J. 2016. Eradicating predators and rodents: the Biological Survey offends scientists to serve the livestock industry. Pp. 105-113 in United States Biological Survey: a compendium of its history personalities, impacts, and conflicts (D. J. Schmidly, W. E. Tydeman, and A. L. Gardner, eds.). Special Publications 64, Museum of Texas Tech University, Lubbock.

Schmidly, D. J. 2012. Obituary: Donald Frederick Hoffmeister: 1916-2011. Journal of Mammalogy 93:871-878.

SchmidLy, D. J. 2016. Vernon Bailey (1864-1942): chief field naturalist of the Biological Survey. Pp. 25-53 in United States Biological Survey: a compendium of its history personalities, impacts, and conflicts (D. J. Schmidly, W. E. Tydeman, and A. L. Gardner, eds.). Special Publications 64, Museum of Texas Tech University, Lubbock.

Schmidly, D. J., AND V. Naples. 2019. North American mammalogy: early history, dominant personalities, and significant milestones (1850-1960). Journal of Mammalogy 100:701-718.

Smith, F. A., AND D. M. Kaufman. 1996. A quantitative analysis of the contributions of female mammalogists from 1919 to 1994. Journal of Mammalogy 77:613-628.

Stein, B. R. 1996. Women in mammalogy: the early years. Journal of Mammalogy 77:629-641.

Stein, B. R. 2001. On her own terms, Annie Montague Alexander and the rise of science in the American West. University of California Press, Berkeley.

Verts, B. J., AND E. C. Birney. 1994. Publications. Pp. 139-154 in Seventy-five years of mammalogy (1919-1994) (E. C. Birney and J. R. Choate, eds.). Special Publication 11, American Society of Mammalogists, Lawrence, Kansas.

Submitted 20 August 2018. Accepted 12 January 2019.

Special Issue Editor was Barbara H. Blake. 